\title{
Combination of Loop-Mediated Isothermal Amplification and AuNP-Oligoprobe Colourimetric Assay for Pork Authentication in Processed Meat Products
}

\author{
Pattanapong Thangsunan $^{1} \cdot$ Sasithon Temisak ${ }^{1} \cdot$ Phattaraporn Morris $^{1} \cdot$ Leonardo Rios-Solis $^{2,3}$ (D) Nuttee Suree ${ }^{4,5}$
}

Received: 9 July 2020 / Accepted: 15 October 2020 / Published online: 26 October 2020

(C) The Author(s) 2020

\begin{abstract}
Pork adulteration is a major concern for Muslims and Jews whose diets are restricted by religious beliefs, as well as those who are allergic to pork meat and its derivatives. Accurate pork authentication is of great importance to assist this demographic group of people in making decision on their product purchase. The aim of this study was to develop a new analytical method for pork authentication in processed meat products based on a combination of loop-mediated isothermal amplification (LAMP) and AuNP-nanoprobe colourimetric assay. The LAMP conditions were first optimised to obtain the highest yield of amplified DNA products within the shortest time. Oligoprobe-functionalised AuNPs were then hybridised with LAMP-DNA amplicons and subsequently challenged with $\mathrm{MgSO}_{4}$ at a high concentration to induce AuNP aggregation. In the presence of pork DNA, the colloidal AuNP-probe remained unchanged in its red colour, which indicates the dispersion of AuNPs. In contrast, in the absence of pork DNA, the colour was changed to colourless as a result from the aggregation of AuNPs. The LAMP-AuNP-nanoprobe assay offers a high sensitivity with a limit of detection as low as $100 \mathrm{pg}$ of pork DNA. The assay is highly specific to pork content without cross-reactivity with the other meat species tested. The assay developed herein can become a simple, inexpensive, precise, and rapid analytical tool for small laboratories or the general public interested in halal food authentication.
\end{abstract}

Keywords Pork authentication - Pork adulteration · Halal food authentication · Loop-mediated isothermal amplification · AuNP-nanoprobe colourimetric assay

Electronic supplementary material The online version of this article (https://doi.org/10.1007/s12161-020-01901-5) contains supplementary material, which is available to authorized users.

Leonardo Rios-Solis

Leo.Rios@ed.ac.uk

$\triangle$ Nuttee Suree

nuttee.suree@cmu.ac.th

1 Bioanalysis Group, Chemical Metrology and Biometry Department, National Institute of Metrology, Pathum Thani, Thailand

2 Institute for Bioengineering, School of Engineering, University of Edinburgh, Edinburgh, UK

3 Centre for Synthetic and Systems Biology (SynthSys), University of Edinburgh, Edinburgh, UK

4 Division of Biochemistry and Biochemical Technology, Department of Chemistry, Faculty of Science, Chiang Mai University, Chiang Mai, Thailand

5 Center of Excellence in Materials Science and Technology, Faculty of Science, Chiang Mai University, Chiang Mai, Thailand

\section{Introduction}

Consumers have generally been concerned about the composition of food they consume, particularly due to the preference on meat products and religious beliefs, as well as health issues (Alikord et al. 2017; Ballin 2010; Farag et al. 2015). Over the past decade, adulteration in meat products has also been widely reported (Kane and Hellberg 2016; Pinto et al. 2015). Meat adulteration can include substitution of higher-valued meats with lower-valued ones, intentional mixing of undeclared meat types or ingredients, additions of plant proteins instead of meat content, and unintentional contamination during processing (Barakat et al. 2014; Cawthorn et al. 2013). These activities may negatively affect consumers' trust on food quality and safety. Therefore, accurate labelling of food products will not only help to protect the consumers from fraudulent actions, but also promote fair trades in local and international levels (Alikord et al. 2017; Barakat et al. 2014; Nešić et al. 2017). For this reason, approaches for identification of meat species have been of great interest in order to support the food industry and to help customers in making decision on food products. 
Many analytical techniques, based on anatomical, histological, microscopic, organoleptic, electrophoretic, chromatographic, and immunological principles, have been developed for the authentication of meat species (Nešić et al. 2017). However, many of these techniques exhibit low sensitivity or are unsuitable for complex and processed food samples (Alikord et al. 2017). DNA detection methods have been of great interest since the structure of DNA is highly stable at high temperature, especially during the food processing steps, while proteins can be denatured, rendering them unsuitable analytes for accurate identification (Ballin et al. 2009). The most frequently used DNA detection techniques for meat identification are based on polymerase chain reaction (PCR) such as randomly amplified polymorphic DNA-PCR (RAPDPCR), restriction fragment length polymorphism-PCR (RFLP-PCR), PCR with species-specific primers, real-time PCR/quantitative PCR (RT-PCR/qPCR), and digital PCR (dPCR) (Alikord et al. 2017; Ballin et al. 2009; Farag et al. 2015). Despite their high sensitivity and specificity, PCR methods have some limitations including their complicated experimentation, the need of a thermal cycler or an additional detection machine, their relatively high cost of reagents and time consumption, and the need of skilled operators (Ali et al. 2012; Ckumdee et al. 2016; Seetang-Nun et al. 2013; Takano et al. 2017; Tomita et al. 2008). This thus presents an opportunity for developing novel and more efficient approaches for authenticating meat species.

In 2000, Notomi and colleagues developed a novel nucleic acid amplification technique called the loop-mediated isothermal amplification (LAMP) (Notomi et al. 2000). LAMP can efficiently work at a constant temperature using a DNA polymerase enzyme with strand displacement ability together with a set of four primers designed from six distinct regions on the target DNA sequence (Notomi et al. 2000; Tomita et al. 2008). The technique is known for its high specificity and selectivity, high cost-effectiveness, fast processing time, and independency from expensive equipment (Tomita et al. 2008). As a result, LAMP has been used in a wide range of applications to overcome the limitations of PCR (Becherer et al. 2020; Kundapur and Nema 2016; Martzy et al. 2019; Mori et al. 2013; Tasrip et al. 2019). Among those applications, LAMP can be combined with other systems to allow better detection of the amplified products. For example, gold nanoparticle (AuNP) colourimetric assay is a visual detection platform based upon aggregation and dispersion of gold nanoparticles (Aldewachi et al. 2018). AuNPs possess a unique property known as surface plasmon resonance (SPR). The increase of AuNP size induces the interparticle plasmon coupling, causing a red shift of the SPR band towards a longer wavelength (Aldewachi et al. 2018; Radwan and Azzazy 2009; Zeng et al. 2011; Zhao et al. 2008). Therefore, as the formation of AuNP aggregates occurs, a transition of solution colour from red to blue or purple can be visible to the naked eyes (Aldewachi et al. 2018; Zhao et al.
2008). Stability of AuNPs in a solution can be modulated through cross-linking and non-cross-linking mechanisms (Zhao et al. 2008). Biological events such as an interaction of antigen-antibody and a hybridisation of DNA can be used to stabilise or destabilise colloidal AuNPs by controlling the net potential between interparticle attractive and repulsive forces (Aldewachi et al. 2018; Glomm 2005; Napper 1984; de Vasconcelos et al. 2005; Walker and Grant 1996; Zhao et al. 2008). While the LAMP method generates DNA amplicons, its combination with the AuNP colourimetry can enable a clear and sensitive detection of DNA or RNA of interest. To this end, the LAMP-gold nanoprobe methods have been applied successfully for a wide range of fields including diagnosis of diseases (Lou et al. 2020; Najian et al. 2016; Qiuhua et al. 2014), microbial drug resistance (Ckumdee et al. 2016; Veigas et al. 2013), forensic sciences (Watthanapanpituck et al. 2014), and pathogen detection in foods (Garrido-Maestu et al. 2017; Kong et al. 2018; Seetang-Nun et al. 2013; Suebsing et al. 2013; Wachiralurpan et al. 2018).

Pork, aside from being one of the most widely consumed meats in the world (FAO 2019; USDA 2018), tends to be a source of adulteration in other meat products such as beef and lamb, mainly due to its cheaper price and similarity in colour and texture (Barakat et al. 2014; Wissiack et al. 2003). Accurate pork authentication is not only necessary for Muslims and Jews, whose religious beliefs highly influence the choice of meat consumption (Barakat et al. 2014; Sheikha et al. 2017), but also for those who are allergic to pork and pigderived product varieties (Fournier et al. 2011; Mamikoglu 2005). In this study, a new analytical platform based on a combination of loop-mediated isothermal amplification with AuNP-nanoprobes was developed in order to authenticate pork content in commercial processed meat products. With its high sensitivity, specificity, efficiency, and simplicity, requiring basic instruments like water baths and heating blocks, this novel method has high potential to become widely used both in food laboratories and in the food industry.

\section{Materials and Methods}

\section{Sample Preparation and DNA Extraction}

Fresh pork (Sus scrofa), chicken (Gallus gallus), duck (Anas platyrhynchos), sheep (Ovis aries), salmon (Salmo salar), and other processed meat products (2 samples of pork sausage, pork ball, chicken burger, beef burger, and shrimp dumpling) were purchased from supermarkets in Pathum Thani, Thailand. Fresh beef meat (Bos taurus) was obtained from a halal food market in Pathum Thani, Thailand. All meat samples were individually blended and freeze-dried (CHRIST, Gamma 1-16 LSC, Germany). The dried meat samples were 
then sieved through $300-\mu \mathrm{m}$ standard test sieves (Retsch, Fisher Scientific, USA) and stored at $-80^{\circ} \mathrm{C}$ until further use.

To obtain genomic DNA, $2 \mathrm{~g}$ of meat or processed food powder was extracted and purified using DNeasy Mericon Food Kit (Qiagen, Germany) according to the manufacturer's instructions. After that, purified DNA samples were determined for their concentration and purity using UV-Vis spectroscopy with a microplate reader (Tecan Spark, Switzerland).

\section{Plasmid Construction}

The partial mitochondrial DNA sequences of Sus scrofa (GenBank accession no. AF034253) and Bos taurus (GenBank accession no. AY526085) were amplified using the primers shown in Table 1. The expected size of PCR products for $S$. scrofa and B. taurus was $622 \mathrm{bp}$ and $585 \mathrm{bp}$, respectively. The PCR reaction with a total volume of $25 \mu \mathrm{l}$ was prepared as follows: $1 \mathrm{x}$ of PCR buffer, $0.2 \mu \mathrm{M}$ dNTP mix, $1.5 \mathrm{mM} \mathrm{MgCl}_{2}, 0.3 \mu \mathrm{M}$ each of forward and reverse primers (Table 1), $50 \mathrm{ng}$ of pork or beef genomic DNA, and 2.5 U Taq DNA polymerase (Invitrogen, USA). PCR cycle started with initial denaturation at $94{ }^{\circ} \mathrm{C}$ for 3 min, followed by 35 cycles of denaturation at $94{ }^{\circ} \mathrm{C}$ for $45 \mathrm{~s}$, annealing at $55^{\circ} \mathrm{C}$ for $30 \mathrm{~s}$, and extension at $72{ }^{\circ} \mathrm{C}$ for $45 \mathrm{~s}$, which then ended with a final extension at $72{ }^{\circ} \mathrm{C}$ for $10 \mathrm{~min}$. The PCR products were analysed using $1.5 \%$ agarose gel electrophoresis in 1x Tris-borate-EDTA (TBE) buffer and purified from the gel using a NucleoSpin ${ }^{\circledR}$ gel and PCR clean-up kit (Macherey-Nagel, Germany).

To construct plasmids, the PCR fragments were ligated into pCR® 2.1 vector (Invitrogen, USA) according to the manufacturer's instructions. The ligated plasmids were transformed into One Shot ${ }^{\mathrm{TM}}$ Top10F' Chemically Competent Escherichia coli (Invitrogen, USA) by heat-shock method. The E. coli was grown on LB agar plus $100 \mu \mathrm{g} / \mathrm{ml}$ ampicillin prior to bluewhite colony selection. Some of the white colonies were picked and cultured in LB broth plus $100 \mu \mathrm{g} / \mathrm{ml}$ ampicillin. The plasmids were purified using a QIAprep® Spin Miniprep kit (Qiagen, Germany) according to the manufacturer's protocol. Purified plasmid concentration was examined using a NanoDrop One UV-Vis spectrophotometer (Thermo Scientific, USA).

\section{LAMP Primer Design}

The partial mitochondrial DNA sequence of $S$. scrofa was exploited to design a set of LAMP primers via Primer Explorer version 5 (https://primerexplorer.jp/e/v5_manual/ index.html). The details of primer locations and sequences are presented in Fig. S1 and Table 1. All of the primers used were synthesised and purified using PAGE by Macrogen Inc. (Korea).

\section{LAMP Assay}

The method for LAMP was modified from the previously published work (Tomita et al. 2008). LAMP reactions at a final volume of $12.5 \mu \mathrm{l}$ were prepared. Each reaction contained $1.6 \mu \mathrm{M}$ each of the inner primers (SUS-mtDNAFIP and SUS-mtDNA-BIP in Table 1), $0.2 \mu \mathrm{M}$ each of the outer primers (SUS-mtDNA-F3 and SUS-mtDNA-B3 in Table 1), $1.4 \mathrm{mM}$ of dNTP mix, $6 \mathrm{mM}$ of $\mathrm{MgSO}_{4}, 0.4 \mathrm{M}$ of betaine (Sigma-Aldrich, USA), 8 U of Bst DNA polymerase (large fragment; New England Biolabs Inc., Beverly, MA, USA), $1 \mathrm{x}$ of the supplied buffer, and a variable amount of DNA template. Plasmid DNA containing S. scrofa
Table 1 Nucleotide sequences for the primers and oligoprobe used in this study

\begin{tabular}{llc}
\hline Primer/probe & Nucleotide sequence $\left(5^{\prime}\right.$ to $\left.3^{\prime}\right)$ & $\begin{array}{l}\text { Number of } \\
\text { base (bp) }\end{array}$ \\
\hline Primers for plasmid construction & 22 \\
Pork-mtDNA-F & AAATACGTGCTACGAAAGCAGG & 24 \\
Pork-mtDNA-R & CTATCGTGTGTCAGGATTATTAGA & 22 \\
Beef-mtDNA-F & TCTACCACCACTTTTAACAGAC & 22 \\
Beef-mtDNA-R & ATAGTGCGTCGGCTATTGTAGG & \\
Primers and probe for LAMP and AuNP-oligoprobe assays & 32 \\
Sus-mtDNA-probe & Thiol-AAAAAAAAAACACAATCTGAATATAGCTTATA & 21 \\
Sus-mtDNA-F3 & ATTTTTACGCCAATCTACCAT & 18 \\
Sus-mtDNA-B3 & GAAAGGCCAGGACCAAAC & 55 \\
Sus-mtDNA-FIP & ATAAGCTATATTCAGATTGTGGGCGTTTTTCACAATAA & 50 \\
Sus-mtDNA-BIP & CCTCCCATAATATATGC & \\
& GCTTAAATTATCAAAGCAAGGCACTTTTTTTGTGTGTT & \\
\hline
\end{tabular}


mitochondrial DNA sequence (pCR-pork-mtDNA plasmidFig. S2) was used as a positive control while sterile $\mathrm{ddH}_{2} \mathrm{O}$ was utilised as a no template control (NTC) for the entire experiments. All of the LAMP reactions were performed at $61^{\circ} \mathrm{C}$ for $45 \mathrm{~min}$ unless stated otherwise, followed by enzyme inactivation at $90{ }^{\circ} \mathrm{C}$ for $2 \mathrm{~min}$. All of the experiments were replicated in at least triplicate. The LAMP products were analysed using $2 \%$ agarose gel electrophoresis in $1 \mathrm{x}$ TBE buffer.

\section{Functionalisation of AuNPs}

The sequence used for designing a ssDNA probe was obtained from mitochondrial DNA of S. scrofa and thiolated at the 5'end (Table 1). Twenty-nanometre AuNPs (Sigma-Aldrich, USA) were functionalised with the thiolated oligoprobe according to the method modified from the previously published work (Hill and Mirkin 2006). In brief, $1 \mathrm{ml}$ of $1 \mathrm{nM}$ of the colloidal AuNP solution was incubated with 4 nmol of freshly DTT-reduced oligoprobe overnight at room temperature with gentle agitation. Phosphate-buffered saline (PBS, pH 7.0) and sodium dodecyl sulfate (SDS) were sequentially added to the AuNP-oligoprobe solution to a final concentration of $9 \mathrm{mM}$ and $0.1 \%(\mathrm{w} / \mathrm{v})$ respectively. Salting buffer containing $10 \mathrm{mM}$ PBS and $2 \mathrm{M} \mathrm{NaCl}$ was then added to the solution by making six additions over the course of 2 days to reach a final $\mathrm{NaCl}$ concentration of $0.3 \mathrm{M}$. After the last $\mathrm{NaCl}$ addition and overnight incubation, the oligoprobe-coated AuNPs were washed three times in $500 \mu \mathrm{l}$ of assay buffer containing $10 \mathrm{mM}$ PBS, $150 \mathrm{mM} \mathrm{NaCl}$, and $0.1 \%$ (w/v) SDS, $\mathrm{pH} \mathrm{7.4.} \mathrm{The}$ functionalised AuNPs were resuspended in the assay buffer to obtain a stock concentration of $2 \mathrm{nM}$ and stored in the dark at room temperature until further use.

\section{AuNP-Oligoprobe Colourimetric Assay for a Proof of Concept}

The proof of concept experiment was conducted in a reaction with a total volume of $10 \mu \mathrm{l}$. In each reaction, $5 \mu \mathrm{l}$ of AuNPnanoprobe was incubated with $2.5 \mu \mathrm{l}$ of $10 \mu \mathrm{M}$ ssDNA target at $61{ }^{\circ} \mathrm{C}$ for $15 \mathrm{~min}$. The sequence for ssDNA complementary to the nanoprobe was 5'-TATAAGCTATATTCAGATTG TG-3', whereas that for non-complementary ssDNA was 5'AACTCGGATACCCAAGGTCTTAC-3'. NTC for this experiment was sterile $\mathrm{ddH}_{2} \mathrm{O}$. After hybridisation, the solution was mixed with $0.5 \mathrm{M} \mathrm{MgSO}_{4}$ and incubated for $30 \mathrm{~min}$ at room temperature. The transition of AuNP-nanoprobe solution colour was visually observed and the absorbance of 400$700 \mathrm{~nm}$ was examined using a microplate reader (Tecan Spark, Switzerland). The experiments were replicated in at least triplicate.

\section{AuNP-Oligoprobe Colourimetric Assay for LAMP Product Testing}

The colourimetric assays were performed in a total reaction volume of $10 \mu \mathrm{l}$. In each reaction, $5 \mu \mathrm{l}$ of oligoprobefunctionalised AuNPs was incubated with $2.5 \mu$ of LAMP products at $61{ }^{\circ} \mathrm{C}$ for $15 \mathrm{~min}$. After hybridisation, $2.5 \mu \mathrm{l}$ of $2 \mathrm{M} \mathrm{MgSO}_{4}$ was added and the solution was incubated for $30 \mathrm{~min}$ at room temperature. The change of solution colour was determined by visual observation and UV-Vis spectroscopy between 400 and $700 \mathrm{~nm}$ using a Spark® multimode microplate reader (Tecan, Switzerland). All of the experiments were replicated in at least triplicate.

\section{Primer-Specific PCR for Meat Species Specificity}

The primers for specific PCR were obtained from the previous study (Montiel-Sosa et al. 2000), which were designed for pork D-loop mitochondrial DNA. The sequence for the forward primer (Pig-F) was 5'-AACCCTATGTACGT CGTGCAT-3', whereas that for the reverse primer (Pig-R) was 5'-ACCATTGACTGAATAGCACCT-3'. Each $25 \mu \mathrm{lre}$ action of PCR contained 1x Pfx amplification buffer, $1 \mathrm{mM}$ $\mathrm{MgSO}_{4}, 0.3 \mathrm{mM}$ dNTP mix, $0.3 \mu \mathrm{M}$ each of forward and reverse primers, $20 \mathrm{ng}$ DNA template, and 1.25 U Platinum Pfx DNA polymerase (Invitrogen, USA). The PCR cycle started from $94{ }^{\circ} \mathrm{C}$ for $2 \mathrm{~min}$, followed by 30 cycles of $94{ }^{\circ} \mathrm{C}$ for $15 \mathrm{~s}, 58^{\circ} \mathrm{C}$ for $30 \mathrm{~s}$, and $68^{\circ} \mathrm{C}$ for $45 \mathrm{~s}$. The PCR was ended with final extension at $68{ }^{\circ} \mathrm{C}$ for $5 \mathrm{~min}$. The PCR products were analysed with $1.5 \%$ agarose gel electrophoresis in 1x TBE buffer.

\section{Real-Time PCR for Meat Species Specificity}

The primers and probe for RT-PCR were used according to the previous work (Köppel et al. 2011), which were specific for pork beta-actin gene (GenBank accession no. DQ452569). The sequence for pork_F primer (forward direction) was 5'GGAGTGTGTATCCCGTAGGTG-3' while that for pork_R primer (reverse direction) was 5'-CTGGGGACATGCAG AGAGTG-3'. The sequence for the probe was 5'-FAMTCTGACGTGACTCCCCGACCTGG-BHQ1-3'. In a total volume of $20 \mu \mathrm{l}$, each reaction contained 1x TaqMan Universal PCR mastermix (Applied Biosystems by Thermo Fisher Scientific, USA), $300 \mathrm{nM}$ each of forward and reverse primer, $200 \mathrm{nM}$ of probe, and $30 \mathrm{ng}$ of DNA template. The RT-PCR was performed using a thermo cycler (ABI 7500 Real-Time PCR, Thermo Fisher Scientific, USA) at $95{ }^{\circ} \mathrm{C}$ for $10 \mathrm{~min}$, followed by 45 cycles of $95{ }^{\circ} \mathrm{C}$ for $15 \mathrm{~s}$ and $58{ }^{\circ} \mathrm{C}$ for $1 \mathrm{~min}$. The RT-PCR data were analysed using 7500 Software v2.3 (ABI 7500 Real-Time PCR). 


\section{Results and Discussion}

\section{Optimisation of Condition for LAMP Assays}

To achieve the highest performance of LAMP assays, two parameters for LAMP, melting temperature $\left(T_{\mathrm{m}}\right)$ and incubation period, were optimised. To examine the optimal $T_{\mathrm{m}}$, during performing LAMP reactions, the temperature was varied between 59 and $65{ }^{\circ} \mathrm{C}$. When the plasmid containing pork mitochondrial DNA (pCR-pork-mtDNA plasmid-Fig. S2) was used as a template, LAMP products from the reactions at 59,61 , and $63{ }^{\circ} \mathrm{C}$ showed a similar pattern with intense bands between 200 and 400 bp (Fig. S3). However, the LAMP products obtained from the $65{ }^{\circ} \mathrm{C}$ reaction showed a slightly different pattern with faint $200-400 \mathrm{bp}$ bands, indicating less yield of LAMP products (Fig. S3). No band was observed when using the plasmid carrying beef mitochondrial DNA sequence (pCR-beef-mtDNA plasmid-Fig. S4) as a negative control template (Fig. S3). Since Bst DNA polymerase has the optimal temperature between 60 and $65{ }^{\circ} \mathrm{C}$ (Notomi et al. 2000), the $T_{\mathrm{m}}$ of $61{ }^{\circ} \mathrm{C}$ was selected as an optimal condition for LAMP assays.

The incubation period was also studied as one of the parameters for LAMP. The LAMP $T_{\mathrm{m}}$ was fixed at $61{ }^{\circ} \mathrm{C}$ with incubation period varied from 15 to $60 \mathrm{~min}$. Using pCR-porkmtDNA plasmid (Fig. S2) as a template, LAMP products were detected at $30 \mathrm{~min}$ and the amount of the amplified products increased as the reaction time increased (Fig. S5). The yield of the LAMP products obtained seemed to reach the highest point at 45 min of incubation (Fig. S5). The reactions with pCR-beefmtDNA plasmid (negative control) and $\mathrm{ddH}_{2} \mathrm{O}$ (no template control) did not show any LAMP amplicons (Fig. S5). The optimal incubation time for LAMP in this study was $45 \mathrm{~min}$. Conclusively, the LAMP assays were performed at $61{ }^{\circ} \mathrm{C}$ for $45 \mathrm{~min}$.

\section{Proof of Concept for AuNP Colourimetric Assays}

A proof of concept of AuNP colourimetric assays was performed to assure its detectability in the presence of the target and non-target DNA. AuNPs (20 nm diameter) were coated with a ssDNA probe with a nucleotide sequence specific to pork mitochondrial DNA (Fig. S1). A thiol group was introduced to the $5^{\prime}$-end of the probe to allow the oriented conjugation of the probe on the surface of AuNPs via thiol-metal interactions (Weisbecker et al. 1996).

Functionalised AuNPs were then hybridised with the ssDNA target. After hybridisation, $\mathrm{MgSO}_{4}$ was added as a salt to challenge the stability of AuNPs upon the change of ionic strength of the solution (Burns et al. 2006; Ckumdee et al. 2016; Seetang-Nun et al. 2013). In the presence of ssDNA target with the complementary sequence to the oligoprobe, the solution colour remained red as its original (Fig. 1a), indicating the dispersion of AuNPs. However, with the noncomplementary ssDNA target (negative control) or in the absence of ssDNA (no template control), the solution changed to colourless (Fig. 1a) as a result from the aggregation of AuNPs. UV-Vis spectroscopy was also used to monitor the behaviour of functionalised AuNPs in the presence or absence of the target (Fig. 1b). Surface plasmon spectrum of the AuNPprobe with a complementary target showed a distinct peak at $520 \mathrm{~nm}$ (Fig. 1b), which is common for colloidal $20 \mathrm{~nm}$ AuNPs (Carrillo-Cazares et al. 2017; Haiss et al. 2007). On the contrary, in the absence of a specific target, this spectrum was shifted towards a longer wavelength (Fig. 1b). This event can be explained by the fact that the binding of complementary ssDNA target to the probe on AuNP surface increases electrostatic repulsion forces and steric hindrance from negative charges on phosphate backbone of DNA, leading to high stability of AuNP-probe even though being in high salt concentration environment (Aldewachi et al. 2018; Seetang-Nun et al. 2013). Therefore, the AuNP solution remained red in colour. Without ssDNA target, the charges of AuNP-probe are intolerant to the increase of ionic strength, resulting in AuNP aggregation. Aggregation of AuNPs can be visually detected by the change of solution colour from red to blue/ purple (Aldewachi et al. 2018; Pamies et al. 2014; SeetangNun et al. 2013). In some circumstances, AuNP colour can also turn colourless if the aggregation is extreme, causing the shift of SPR bands to the infra-red region (Aldewachi et al. 2018).

\section{Combination of LAMP and AuNP-Probe Colourimetric Assays}

In this study, LAMP as a tool for target gene amplification and AuNP-probe colourimetric assay as a method for visually detecting the presence of a target of interest were combined to improve the efficiency of pork DNA detection. Two parameters affecting the performance of the assays, which were $\mathrm{MgSO}_{4}$ concentrations and hybridisation temperature, were optimised.

\section{Effects of $\mathrm{MgSO}_{4}$ Concentrations}

The effects of $\mathrm{MgSO}_{4}$ concentrations on the aggregation of AuNP-probe were studied since the ionic strength of salt in aqueous media can modulate the stability of colloidal AuNPs as observed by the transition in colour of colloidal AuNPs (Burns et al. 2006; Pamies et al. 2014; Seetang-Nun et al. 2013). In the present work, $\mathrm{MgSO}_{4}$ was chosen as a salt to induce AuNP aggregation. After hybridisation, the solution of $\mathrm{MgSO}_{4}$ at a concentration of $0.25,0.5,1$, and $2 \mathrm{M}$ was added to the mixture of AuNP-probe and LAMP amplicons. As shown in Fig. $2 \mathrm{a}$, at 0.25 and $0.5 \mathrm{M} \mathrm{MgSO}_{4}$, AuNP-probe colour remained red no matter the DNA templates for 

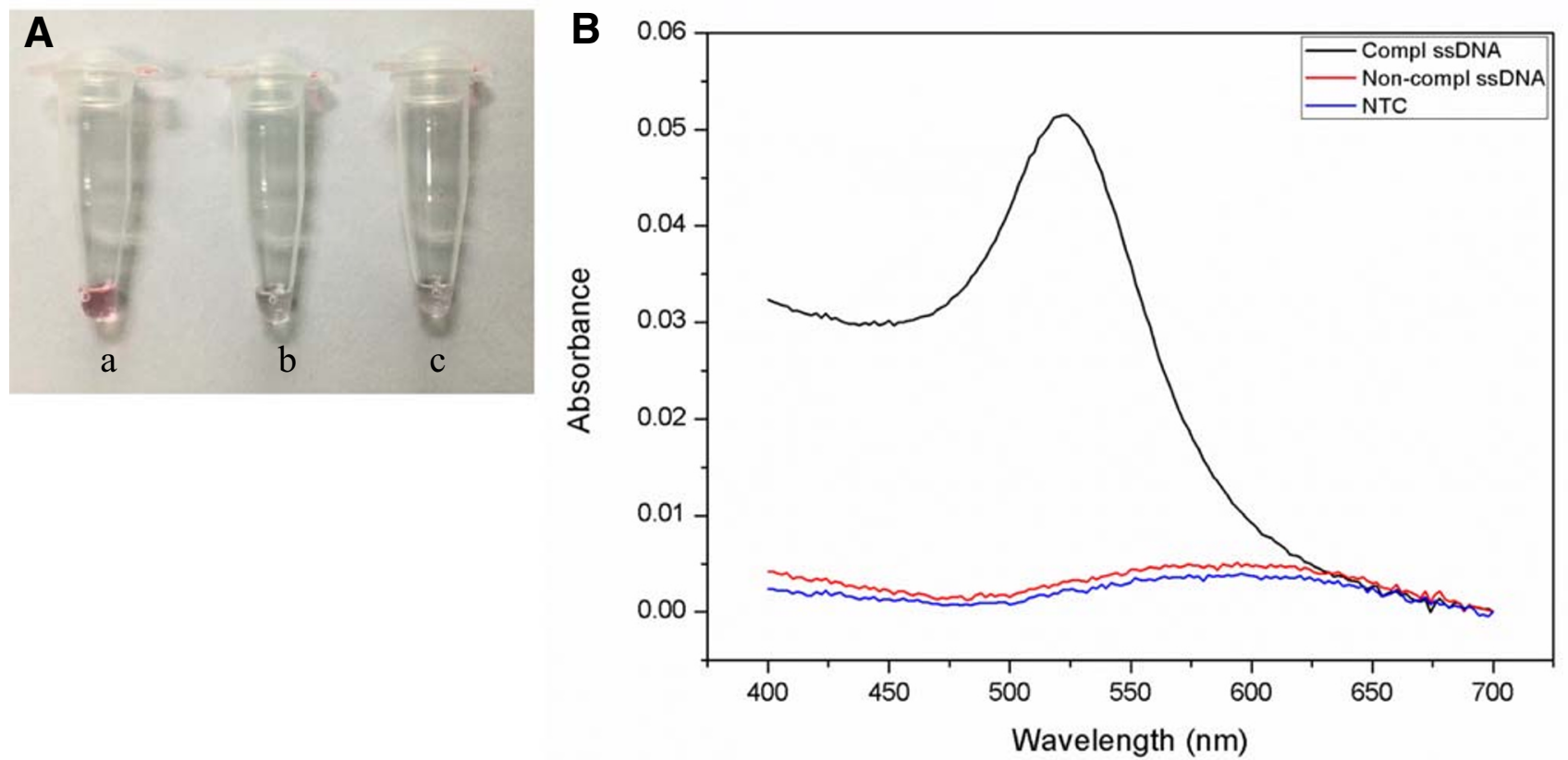

Fig. 1 The proof of concept for AuNP colourimetric assays. a Digital photograph showing the change of colloidal AuNP colour after adding $0.5 \mathrm{M} \mathrm{MgSO}_{4}$ to the solution with (a) $10 \mu \mathrm{M}$ of complementary ssDNA,

LAMP were pCR-pork-mtDNA plasmid (positive control), pork DNA, beef DNA (negative control), or $\mathrm{ddH}_{2} \mathrm{O}$ (NTC). Using $1 \mathrm{M} \mathrm{MgSO}_{4}$, a slight drop of AuNP-probe colour from red to pale red was detected for beef gDNA and NTC reactions while the solution colour for pCR-pork-mtDNA plasmid and pork gDNA remained unchanged (Fig. 2a). A significant change of AuNP colour was observed at $2 \mathrm{M} \mathrm{MgSO}_{4}$ where the solution colour was still red for LAMP products from pCR-pork-mtDNA plasmid and pork gDNA, but became colourless for beef DNA and NTC (Fig. 2a). These data were in good agreement with the UV-Vis spectroscopic data (Fig. 2b). The A520/A650 ratios for AuNP-probe with beef DNA and NTC were decreased with 1 and $2 \mathrm{M} \mathrm{MgSO}_{4}$ whereas those for pCR-pork-mtDNA plasmid and pork DNA remained unchanged (Fig. 2b). No significant changes of the A520/ A650 ratio for all four samples were observed for 0.25 or $0.5 \mathrm{M} \mathrm{MgSO}_{4}$ (Fig. 2b). Thus, $2 \mathrm{M} \mathrm{MgSO}_{4}$ was selected as the optimal concentration of salt used for inducing AuNP aggregation.

\section{Effects of Hybridisation Temperature}

Hybridisation temperature is one of the key factors to achieve AuNP-probe colourimetric assays since it governs a specific interaction between two complementary strands of DNA (Ge et al. 2012; Harris and Kiang 2006; Hottin et al. 2009). In this study, the mixtures of LAMP amplicons and AuNP-probe were hybridised at room temperature, 50 and $61{ }^{\circ} \mathrm{C}$. Figure 3 a reveals that at hybridisation temperature of 50 and $61{ }^{\circ} \mathrm{C}$, the aggregation of AuNPs was observed in LAMP (b) $10 \mu \mathrm{M}$ of non-complementary ssDNA, and (c) sterile $\mathrm{ddH}_{2} \mathrm{O}$ as a no template control. b UV-Vis spectra of AuNP-probe with complementary ssDNA, non-complementary ssDNA, and no template control

reactions from beef DNA and NTC while no aggregates were seen with LAMP products from pCR-pork-mtDNA plasmid (positive control) and pork DNA. However, the rate of AuNP aggregation at $61{ }^{\circ} \mathrm{C}$ was faster than that of $50{ }^{\circ} \mathrm{C}$. At room temperature, a slow AuNP aggregation was found for AuNPs with beef DNA and NTC as observed by a slight drop of red colour of AuNPs (Fig. 3a). This is likely because the rate of hybridisation of LAMP amplicons to oligoprobe takes place more rapidly at higher temperature. The UV-Vis spectroscopic measurement agreed with visual observation results that the temperature of $61{ }^{\circ} \mathrm{C}$ was optimum since it caused the most significant drop of the A520/A650 ratio for non-pork DNA samples (Fig. 3b) whereas the ratios of A520/A650 for pCRpork-mtDNA plasmid and pork DNA remained unchanged for all the hybridisation temperatures tested.

\section{Specificity of LAMP-AuNP Colourimetric Assays}

Specificity of LAMP-AuNP-probe assays was also investigated since cross-reactivity is likely to cause false positives in non-pork-containing samples. LAMP reactions were performed with genomic DNA from pork, beef, chicken, duck, sheep, and salmon. The results from agarose gel electrophoresis showed that LAMP products were only seen in the reactions with pCR-pork-mtDNA plasmid (positive control) and pork DNA while there were no amplified LAMP products in the non-pork DNA samples (Fig. 4a). The LAMP products were then tested using AuNP-probe colourimetric assays and the results revealed that AuNP solution with pCR-porkmtDNA plasmid and pork DNA remained red, whereas the 
Fig. 2 Effects of $\mathrm{MgSO}_{4}$ concentrations on AuNP-probe aggregation. a Digital photographs presenting AuNP-probe after mixing with different concentrations of $\mathrm{MgSO}_{4}$. LAMP products to be tested were amplified from $(\mathrm{P}+), 25 \mathrm{ng}$ of $\mathrm{pCR}$ pork-mtDNA plasmid as a positive control; (Po), 40 ng of pork genomic DNA; (Be), 40 ng of beef genomic DNA; and (NTC), sterile $\mathrm{ddH}_{2} \mathrm{O}$ as a no template control. b A520/A620 ratio of AuNP-probe after adding different concentrations of $\mathrm{MgSO}_{4}$. Data are means $\pm \mathrm{SD}(n=8)$ $\mathbf{a}$

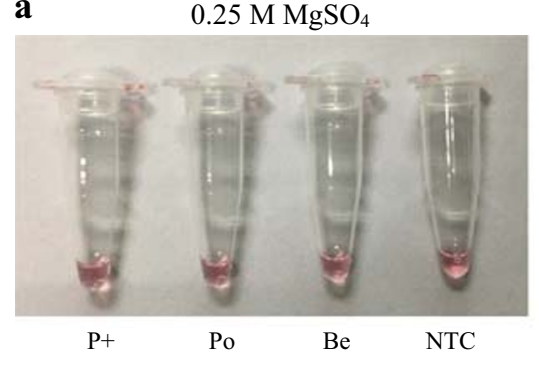

$1 \mathrm{M} \mathrm{MgSO}_{4}$



$0.5 \mathrm{M} \mathrm{MgSO}_{4}$

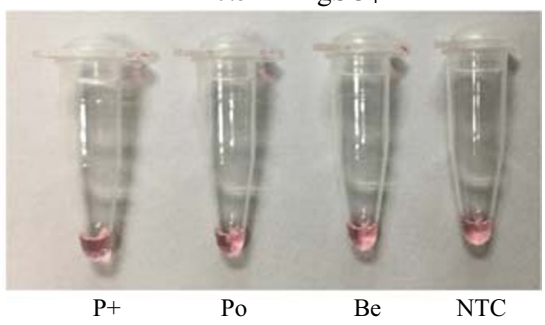

$2 \mathrm{M} \mathrm{MgSO}_{4}$

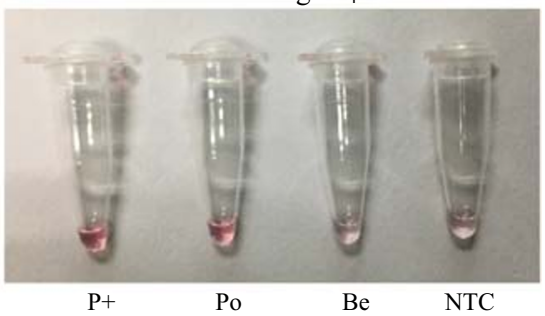

b

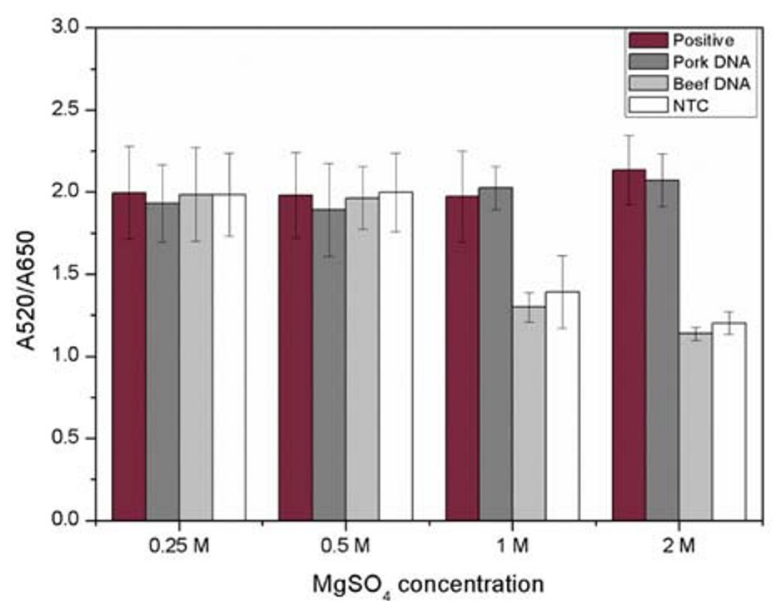

solution of the rest samples changed to colourless, indicating the aggregation of AuNPs (Fig. 4b). The AuNP-probe solutions with LAMP products were determined with UV-Vis spectroscopy. The spectroscopic results agreed with agarose gel electrophoresis and visual observation as the unchanged A520/A650 ratios were seen in pCR-pork-mtDNA plasmid and pork DNA samples, but the A520/A650 ratios were decreased in non-pork DNA samples and NTC (Fig. 4c). Taking these data together, the LAMP-AuNP-probe assay developed was highly specific for pork DNA detection.

Primer-specific PCR and RT-PCR were also conducted to compare the specificity for pork identification with the LAMP-AuNP-probe assay. The specific PCR was performed using a pair of primers specific to pork D-loop mitochondrial DNA, which was obtained from Montiel-Sosa et al. (2000). The primers and probe used for RT-PCR provided by Köppel et al. (2011) were specific for pork beta-actin gene. Both primer-specific PCR and RT-PCR showed high specificity for pork identification as the positive detection was only found in the reaction containing pork DNA (Fig. S6 and S7). The specificity of LAMP-AuNP-probe assay was equivalent to the primer-specific PCR and RT-PCR as the same detection results for pork authentication were observed (Table S1).

\section{Sensitivity of the LAMP-AuNP Colourimetric Assay}

Sensitivity of the LAMP-AuNP colourimetric assay was also studied to determine a limit of detection of the assay, which is the lowest concentration of pork DNA template that can be detected. A range of pork DNA concentrations from $10^{2}$ to $10^{-4} \mathrm{ng}$ was prepared and utilised to perform LAMP assays. The results from agarose gel electrophoresis revealed that LAMP products were clearly observed with the initial pork DNA template at a concentration of $10^{2}-10^{-1} \mathrm{ng}$ (Fig. 5a). The products almost disappeared at $10^{-2}$ ng of pork DNA and were undetectable at a concentration of $10^{-3}-10^{-4}$ ng (Fig. 5a). After testing LAMP products with AuNP colourimetric assays, the data obtained from visual observation (Fig. 5b) and UV-Vis spectroscopy (Fig. 5c) showed that at pork DNA concentrations of $10^{2}-10^{-1} \mathrm{ng}$, no AuNP-probe aggregation was observed and 
a

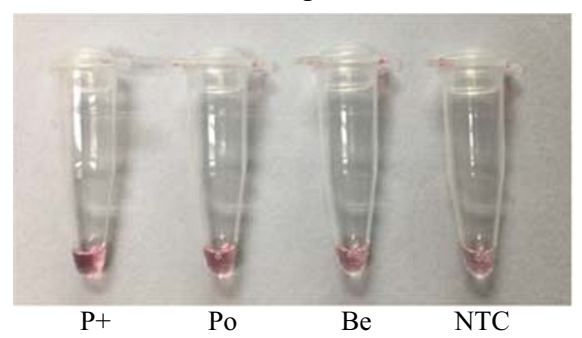

$50{ }^{\circ} \mathrm{C}$

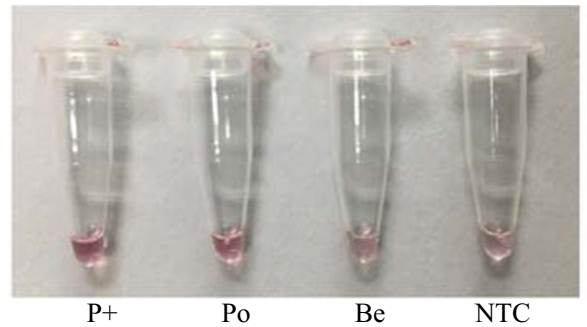

$61{ }^{\circ} \mathrm{C}$

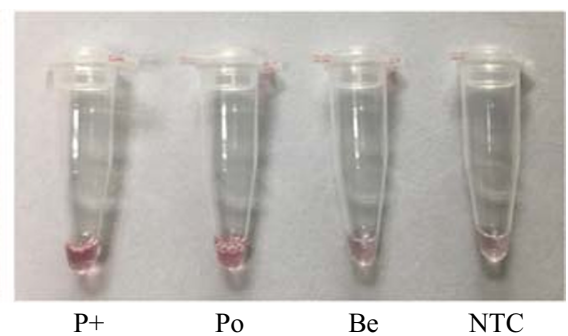

b

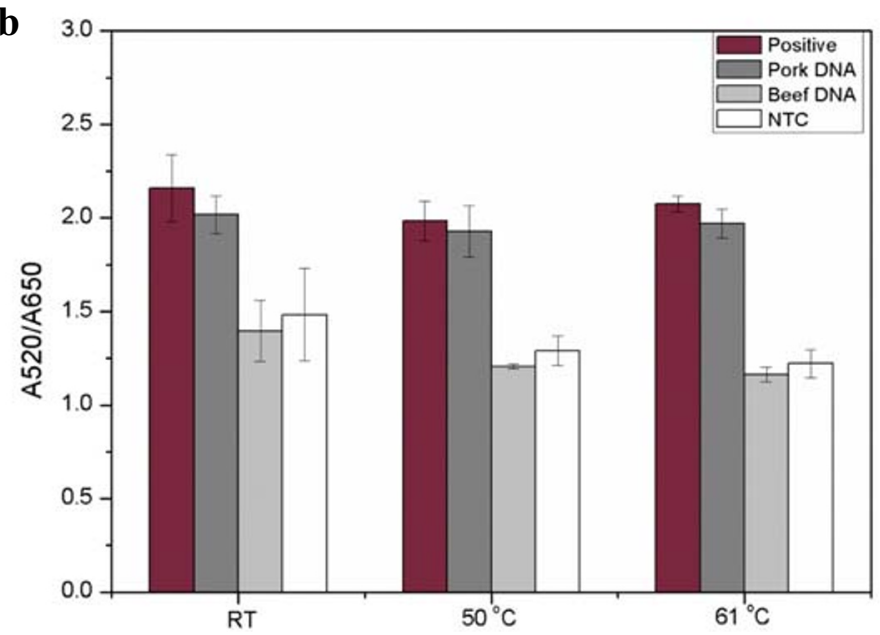

Hybridisation temperature

Fig. 3 Effects of hybridisation temperature on AuNP-probe aggregation. a Digital photographs showing AuNP-probe solution colour after hybridisation at room temperature, 50 and $61{ }^{\circ} \mathrm{C}$. LAMP products to be tested were amplified from ( $\mathrm{P}+), 25 \mathrm{ng}$ of pCR-pork-mtDNA plasmid as a positive control; (Po), 40 ng of pork genomic DNA; (Be), 40 ng of beef genomic DNA; and (NTC), $\mathrm{ddH}_{2} \mathrm{O}$ as a no template control. b A520/ A620 ratio of AuNP-probe after hybridisation at different temperatures. Data are means $\pm \operatorname{SD}(n=6)$ the A520/A650 ratios remained unchanged. However, at pork DNA concentrations between $10^{-2}$ and $10^{-4} \mathrm{ng}$, the solution of AuNP-probe turned colourless (Fig. 5b), indicating the AuNP aggregation with the decrease of A520/A650 ratios (Fig. 5c). The limit of detection (LOD) for LAMP-AuNP-probe assays in this work was as low as $0.1 \mathrm{ng}(=100 \mathrm{pg})$ of pork gDNA template. This LOD falls in the nM-pM range, which is acceptable as compared to other published pork identification methods (Table 2).

\section{Challenge of the LAMP-AuNP-Probe Assay with Processed Food Samples}

The LAMP-AuNP-probe assays were demonstrated for their capability of detecting pork content in process food products collected from supermarkets in Pathum Thani, Thailand. All the processed food products were tested for the presence of pork content by droplet digital PCR (ddPCR) (Temisak et al. 2020) prior to LAMP-AuNP-probe colourimetric assays (Table S2). In Fig. 6a, LAMP assays with agarose gel electrophoresis showed that the amplified products were detected in a sample of pCR-pork-mtDNA plasmid, two samples of pork sausage, and a sample of pork ball. However, no LAMP products were seen in non-pork products which were chicken burger, beef burger, and shrimp dumpling (Fig. 6a). The data from AuNP-probe colourimetric assays also agreed with the results of agarose gel electrophoresis. As seen in Fig. $6 \mathrm{~b}$, the AuNP-probe remained red for the samples containing pork DNA (pCR-pork-mtDNA plasmid, two pork sausage samples and pork ball), indicating no aggregation of AuNPs. These pork DNA-containing samples also showed higher ratios of A520/A650 in UV-Vis spectroscopic measurement (Fig. 6c). On the other hand, non-pork DNA-containing samples (chicken burger, beef burger, shrimp dumpling, and NTC) showed the change of AuNP colour to colourless (Fig. 6b) and lower ratios of A520/A650 (Fig. 6c) as anticipated, indicating the AuNP aggregation. This means that the LAMPAuNP-probe assays developed in this study are capable of detecting pork content in commercial processed food products in the markets. 
a

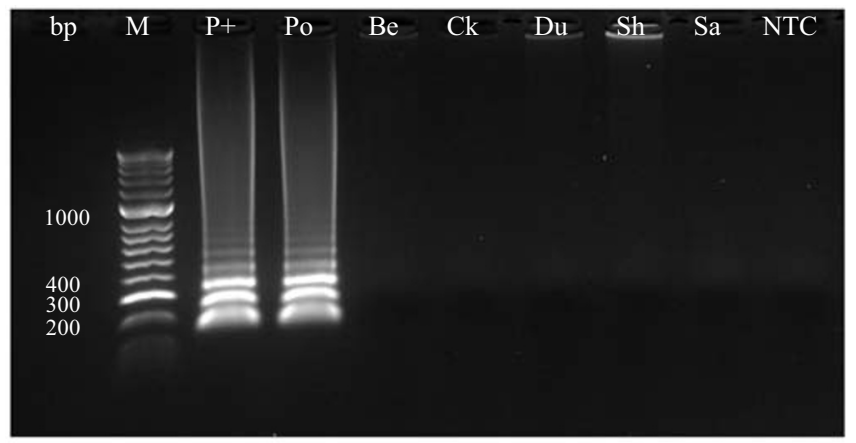

b

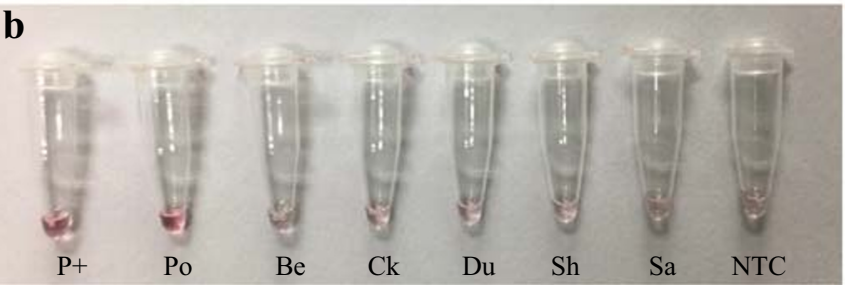

Fig. 4 Specificity of LAMP-AuNP-probe colourimetric assays for genomic DNA from different meat species. a LAMP products analysed by $2 \%$ agarose gel electrophoresis. (M), HyperLadder 50 bp DNA marker (Bioline, UK); $(\mathrm{P}+), 25 \mathrm{ng}$ of pCR-pork-mtDNA plasmid as a positive control; (Po), $40 \mathrm{ng}$ of pork DNA; (Be), $40 \mathrm{ng}$ of beef DNA; (Ck), $40 \mathrm{ng}$ of chicken DNA; (Du), 40 ng of duck DNA; (Sh), 40 ng of sheep DNA;

\section{Efficiency and Limitations of the Assay}

In this work, a new pork authentication method based on a combination of loop-mediated isothermal amplification and AuNP-nanoprobe colourimetric assay has been successfully developed. The technique has been proven for its fast processing time with $45 \mathrm{~min}$ for LAMP assay (Fig. S3) plus $45 \mathrm{~min}$

\section{c}

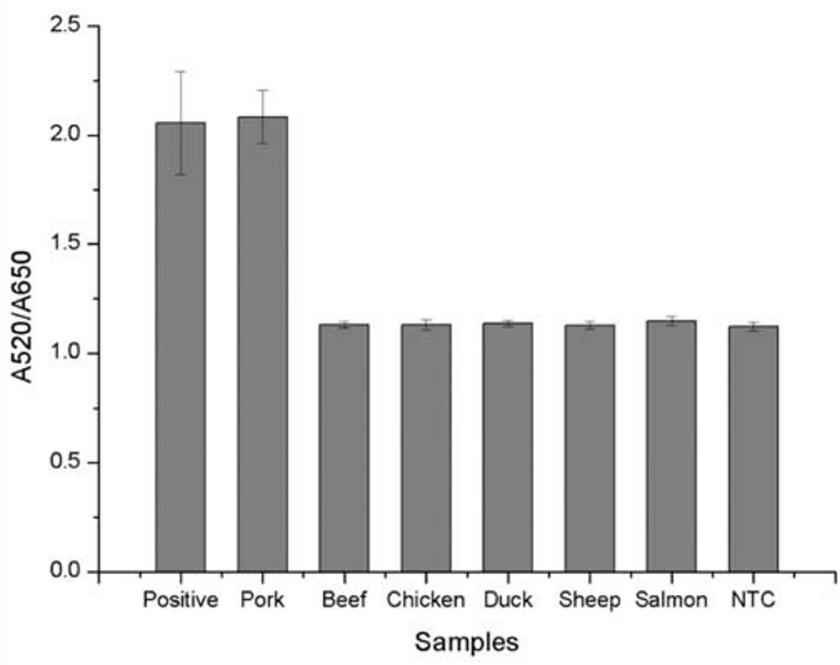

(Sa), $40 \mathrm{ng}$ of salmon DNA; and (NTC), $\mathrm{ddH}_{2} \mathrm{O}$ as a no template control. b Digital photograph showing AuNP-probe solution colour with LAMP products amplified from gDNA from different meat species. c UV-Vis spectroscopic results (A520/A650) for meat species specificity test of LAMP-AuNP-probe assays. Data are means $\pm \operatorname{SD}(n=8)$

for AuNP-oligoprobe assay. The LAMP-AuNP-nanoprobe assay also offers high specificity to the pork content and exhibits no cross-reactivity with other meat species (Figs. 4 and 6). The assay also shows high sensitivity with the limit of detection of pork genomic DNA as low as $100 \mathrm{pg}$ (Fig. 5).

Conventional PCR methods such as RAPD-PCR, RFLP$\mathrm{PCR}$, and PCR with sequence-specific primers have been

Table 2 Sensitivity of PCR-based assays for pork DNA detection

\begin{tabular}{llll}
\hline Methods & Target genes & Limit of detection for pork DNA & References \\
\hline Specific PCR & Mitochondrial D-loop gene & $1 \mathrm{pg} / \mu \mathrm{l}$ & Man et al. (2012) \\
Specific PCR & Mitochondrial D-loop gene & $10 \mathrm{pg}$ & Karabasanavar et al. (2014) \\
Multiplex PCR & Species-specific nuclear DNA (nDNA) & $500 \mathrm{pg}$ & Wang et al. (2020) \\
RT-PCR & Mitochondrial cytochrome b gene & $1 \mathrm{pg}$ & Orbayinah et al. (2019) \\
RT-PCR & Pig mitochondrial DNA & $100 \mathrm{pg}$ & Farrokhi and Joozani (2011) \\
RT-PCR & 12S rRNA gene & $10 \mathrm{pg}$ & Rodríguez et al. (2005) \\
RT-PCR & Mitochondrial D-loop DNA & $0.1 \mathrm{pg}$ & Kim et al. (2016) \\
Multiplex RT-PCR & Beta-actin gene & $150 \mathrm{pg}$ & Cheng et al. (2014) \\
Molecular beacon probe RT-PCR & Cytochrome b gene & $0.1 \mathrm{pg}$ & Yusop et al. (2012) \\
ddPCR & ATPase gene & $2.2 \mathrm{pg}$ & Shehata et al. (2017) \\
Duplex ddPCR & Beta-actin gene & $100 \mathrm{pg} / \mu \mathrm{l}$ & Cai et al. (2017) \\
RT-LAMP & Mitochondrial D-loop gene & $1 \mathrm{pg}$ & Lee et al. (2016) \\
RT-LAMP & Cytochrome b gene & $1 \mathrm{pg}$ & Yang et al. (2014) \\
Gold nanoparticle sensor & Cytochrome b gene & $400 \mathrm{pg} / \mu \mathrm{pl}$ & Ali et al. (2012) \\
LAMP-AuNP-oligoprobe assay & Mitochondrial DNA & $100 \mathrm{pg}$ & This work
\end{tabular}


$\mathbf{a}$

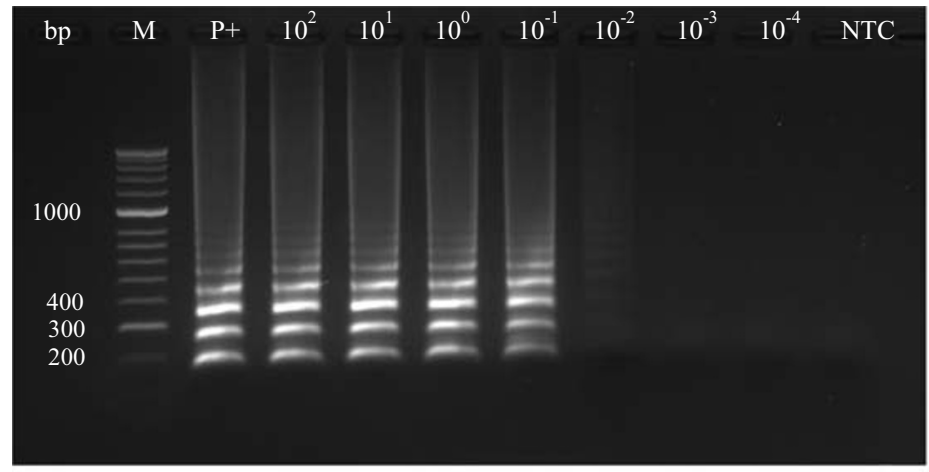

b

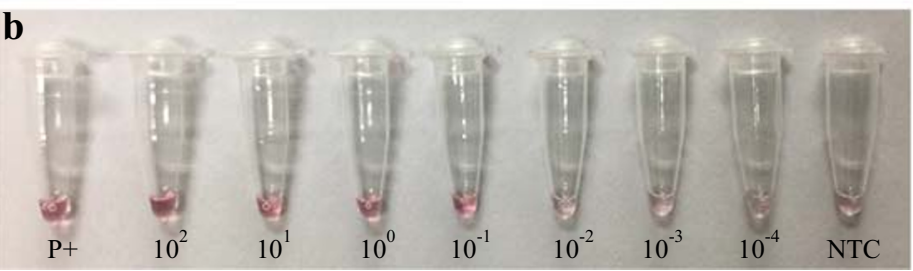

c

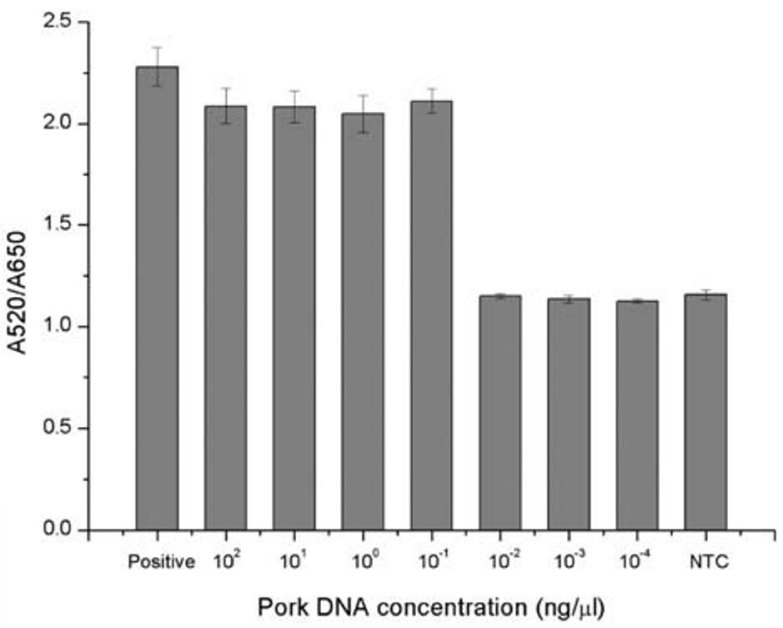

Fig. 5 Sensitivity of LAMP-AuNP-probe colourimetric assays tested with different concentrations of pork genomic DNA. a LAMP products analysed using $2 \%$ agarose gel electrophoresis. (M), HyperLadder $50 \mathrm{bp}$ DNA marker (Bioline, $\mathrm{UK}) ;(\mathrm{P}+), 25 \mathrm{ng}$ of pCR-pork-mtDNA plasmid as a positive control; $\left(10^{2}-10^{-4}\right)$, pork DNA at the concentration of $10^{2}-$
$10^{-4} \mathrm{ng}$; and (NTC), $\mathrm{ddH}_{2} \mathrm{O}$ as a no template control. b Digital photograph showing AuNP-probe solution colour with LAMP products amplified from different concentrations of pork gDNA. $\mathbf{c}$ UV-Vis spectroscopic results (A520/A650) for sensitivity test of LAMP-AuNP-probe assays. Data are means $\pm \operatorname{SD}(n=6)$ a

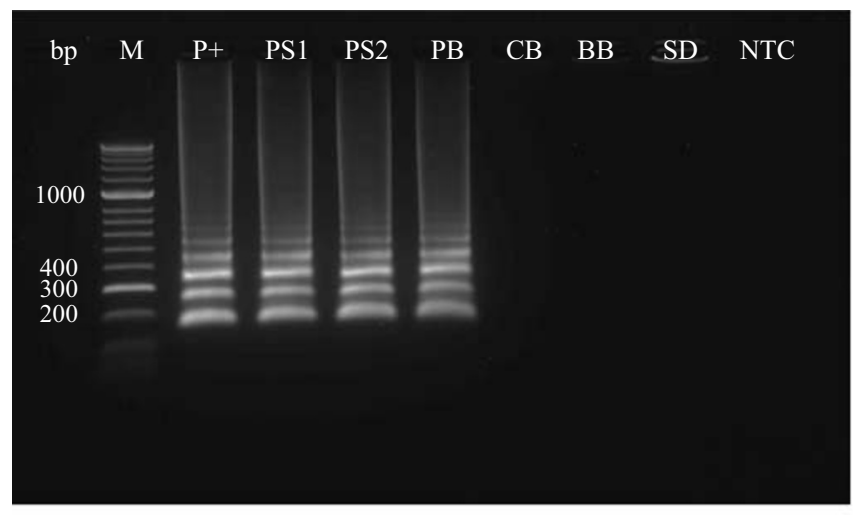

b

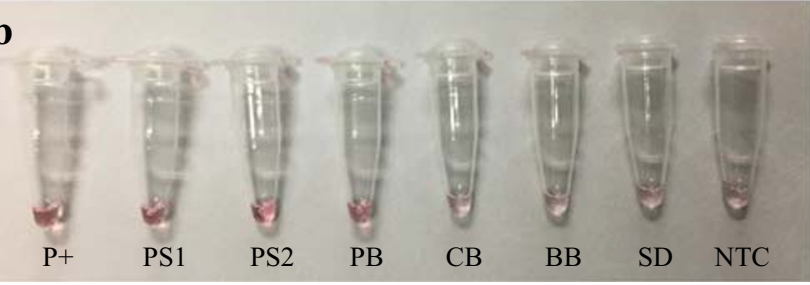

Fig. 6 The challenge of LAMP-AuNP-probe colourimetric assay with processed food products. a LAMP products analysed by $2 \%$ agarose gel electrophoresis. (M), HyperLadder 50 bp DNA marker (Bioline, $\mathrm{UK})$; $(\mathrm{P}+), 25 \mathrm{ng}$ of pCR-pork-mtDNA plasmid as a positive control; $10 \mathrm{ng}$ of DNA extracted from (PS1), pork sausage no. 1; (PS2), pork sausage no. 2; (PB), pork ball; (CB), chicken burger; (BB), beef burger; c

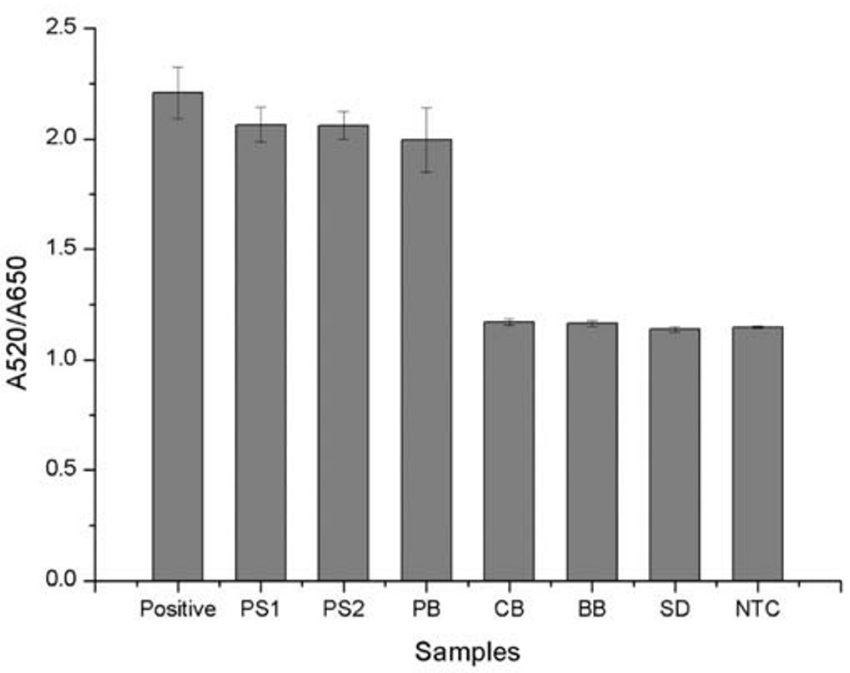

(SD), shrimp dumpling; and (NTC), $\mathrm{ddH}_{2} \mathrm{O}$ as a no template control. b Digital photograph showing AuNP-probe solution colour with LAMP products amplified from processed food product DNA. c UV-Vis spectroscopic results (A520/A650) for LAMP-AuNP-probe assays tested with processed food samples. Data are means $\pm \operatorname{SD}(n=6)$ 
reported for pork identification (Ballin et al. 2009; Man et al. 2012; Mane et al. 2013). Although proven to be specific and sensitive to the targets, the PCR-based techniques are cumbersome due to the requirements of special equipment such as thermal cyclers. They may also require an additional step after performing PCR like gel electrophoresis in order to reveal the outcome (Ali et al. 2012; Calvo et al. 2001a, b; Man et al. 2012; Mane et al. 2013; Murugaiah et al. 2009). The use of LAMP together with AuNP-nanoprobe method developed in this study could be a promising alternative as it can be conducted at a constant temperature and the detection can be clearly observed by the naked eyes. The LAMP-AuNPprobe assay, however, has its limitations as it delivers qualitative information and is less sensitive when compared with the quantitative PCR techniques (Table 2). Real-time PCR (RT-PCR) and digital PCR (dPCR) are the two PCR-based methods that can provide quantitative data with high specificity and sensitivity (Ballin et al. 2009; Cai et al. 2017; Farrokhi and Joozani 2011; Floren et al. 2015; Orbayinah et al. 2019; Rodríguez et al. 2005; Shehata et al. 2017). Nevertheless, both RT-PCR and APCR require relatively expensive reagents as well as special devices to perform the PCR reactions, which may not be affordable for laboratories with limited budgets (Ali et al. 2012; Basu 2017). The LAMP-AuNP-probe assay could thus be a good solution for this problem as it is inexpensive and requires only a simple device that can control the temperature such as a water bath or a heating block.

\section{Conclusion}

In the present study, a new analytical method using a loopmediated isothermal amplification combined with AuNPoligoprobe colourimetric assay has been developed successfully for meat authentication, especially to distinguish pork from other meat products. The assay was highly specific to pork DNA content without cross-reactivity with other meat species. It is highly sensitive with a limit of detection as low as $100 \mathrm{pg}$ of pork DNA. In addition, this method has been proven to be rapid, easy-to-use, and cost-effective, as it only requires simple temperature-controllable devices for the experimentation. No special detection system is required as the transition of colloidal AuNP colour can be readily visually observed. Hence, it is anticipated that the developed method could become a viable alternative for laboratories with limited budget and equipment, rendering authentication of pork or halal food more convenient, yet still precise and reliable.

Funding This work was partially supported by the Global Partnership Project, Thailand Science Research and Innovation (TSRI). N. Suree was also supported by the Materials Science Research Center (MSRC), Chiang Mai University, the Grant for New Researcher (Grant: TRG5880271) from the Thailand Science Research and Innovation (TSRI), the Research Fund for DPST Graduate with First Placement
(Grant: 037/2555), the CMU Young Faculty Research Grant, and the National Research Council of Thailand (Grants: 2556NRCT51390, 2558NRCT350269, and NRCT-PARB/39/2561).

\section{Compliance with Ethical Standards}

Conflict of Interest Pattanapong Thangsunan declares that he has no conflict of interest. Sasithon Temisak declares that she has no conflict of interest. Phattaraporn Morris declares that she has no conflict of interest. Leonardo Rios-Solis declares that he has no conflict of interest. Nuttee Suree declares that he has no conflict of interest.

Ethical Approval This article does not contain any studies with human participants or animals performed by any of the authors.

Informed Consent Not applicable.

Open Access This article is licensed under a Creative Commons Attribution 4.0 International License, which permits use, sharing, adaptation, distribution and reproduction in any medium or format, as long as you give appropriate credit to the original author(s) and the source, provide a link to the Creative Commons licence, and indicate if changes were made. The images or other third party material in this article are included in the article's Creative Commons licence, unless indicated otherwise in a credit line to the material. If material is not included in the article's Creative Commons licence and your intended use is not permitted by statutory regulation or exceeds the permitted use, you will need to obtain permission directly from the copyright holder. To view a copy of this licence, visit http://creativecommons.org/licenses/by/4.0/.

\section{References}

Aldewachi H, Chalati T, Woodroofe MN, Bricklebank N, Sharrack B, Gardiner P (2018) Gold nanoparticle-based colorimetric biosensors. Nanoscale 10:18-33

Ali ME, Hashim U, Mustafa S, Man YBC, Islam KN (2012) Gold nanoparticle sensor for the visual detection of pork adulteration in meatball formulation. J Nanomater 2012:103607

Alikord M, Momtaz H, Keramat J, Kadivar M, Rad AH (2017) Species identification and animal authentication in meat products: a review. Food Measure 12:145-155

Ballin NZ (2010) Authentication of meat and meat products. Meat Sci 86(3):577-587

Ballin NZ, Vogensen FK, Karlsson AH (2009) Species determination — can we detect and quantify meat adulteration? Meat Sci 83(2):165-174

Barakat H, El-Garhy HAS, Moustafa MMA (2014) Detection of pork adulteration in processed meat by species-specific PCR-QIAxcel procedure based on D-loop and cyt b genes. Appl Microbiol Biotechnol 98(23):9805-9816

Basu AS (2017) Digital assays part I: partitioning statistics and digital PCR. SLAS Technol 22(4):369-386

Becherer L, Borst N, Bakheit M, Frischmann S, Zengerle R, Stetten FV (2020) Loop-mediated isothermal amplification (LAMP)—review and classification of methods for sequence specific detection. Anal Methods 12:717-746

Burns C, Spendel WU, Puckett S, Pacey GE (2006) Solution ionic strength effect on gold nanoparticle solution color transition. Talanta 69:873-876

Cai Y, He Y, Lv R, Chen H, Wang Q, Pan L (2017) Detection and quantification of beef and pork materials in meat products by duplex droplet digital PCR. PLoS One 12(8):e0181949 
Calvo JH, Zaragoza P, Osta R (2001a) Random amplified polymorphic DNA fingerprints for identification of species in poultry pâté. Poult Sci 80(4):522-524

Calvo JH, Zaragoza P, Osta R (2001b) Technical note: a quick and more sensitive method to identify pork in processed and unprocessed food by PCR amplification of a new specific DNA fragment. J Anim Sci 79(8):2108-2112

Carrillo-Cazares A, Jiménez-Mancilla NP, Luna-Gutiérrez MA, IsaacOlivé K, Camacho-López MA (2017) Study of the optical properties of functionalized gold nanoparticles in different tissues and their correlation with the temperature increase. J Nanomater 2017: 3628970

Cawthorn DM, Steinman HA, Hoffman LC (2013) A high incidence of species substitution and mislabelling detected in meat products sold in South Africa. Food Control 32(2):440-449

Cheng X, He W, Huang F, Huang M, Zhou G (2014) Multiplex real-time PCR for the identification and quantification of DNA from duck, pig and chicken in Chinese blood curds. Food Res Int 60:30-37

Ckumdee J, Kaewphinit T, Chansiri K, Santiwatanakul S (2016) Development of Au-nanoprobes combined with loop-mediated isothermal amplification for detection of isoniazid resistance in Mycobacterium tuberculosis. J Chemother 2016:3474396

de Vasconcelos CL, Pereira MR, Fonseca JLC (2005) Polyelectrolytes in solution and the stabilization of colloids. J Dispers Sci Technol 26(1):59-70

FAO (2019) Meat market review-overview of global meat market developments in 2018. Food and Agriculture Organization of the United Nations, Rome

Farag MR, Alagawany M, El-Hack MEA, Tiwari R, Dhama K (2015) Identification of different animal species in meat and meat products: trends and advances. Adv Anim Vet Sci 3(6):334-346

Farrokhi R, Joozani RJ (2011) Identification of pork genome in commercial meat extracts for Halal authentication by SYBR green I realtime PCR. Int J Food Sci Technol 46:951-955

Floren C, Wiedemann I, Brenig B, Schütz E, Beck J (2015) Species identification and quantification in meat and meat products using droplet digital PCR (ddPCR). Food Chem 173:1054-1058

Fournier PE, Thuny F, Grisoli D, Lepidi H, Vitte J, Casalta JP, Weiller PJ, Habib G, Raoult D (2011) A deadly aversion to pork. Lancet 377: 1542

Garrido-Maestu A et al (2017) Combination of microfluidic loopmediated isothermal amplification with gold nanoparticles for rapid detection of Salmonella spp. in food samples. Front Microbiol 8: 2159

Ge D, Wang X, Williams K, Levicky R (2012) Thermostable DNA immobilization and temperature effects on surface hybridization. Langmuir 28(22):8446-8455

Glomm WR (2005) Functionalized gold nanoparticles for applications in bionanotechnology. J Dispers Sci Technol 26(3):389-414

Haiss W, Thanh NTK, Aveyard J, Fernig DG (2007) Determination of size and concentration of gold nanoparticles from UV-Vis spectra. Anal Chem 79(11):4215-4221

Harris NC, Kiang CH (2006) Defects can increase the melting temperature of DNA-nanoparticle assemblies. J Phys Chem B 110(33): 16393-16396

Hill HD, Mirkin CA (2006) The bio-barcode assay for the detection of protein and nucleic acid targets using DTT-induced ligand exchange. Nat Protoc 1(1):324-336

Hottin J, Moreau J, Canva M (2009) Temperature impact on thermodynamical parameters of DNA: DNA hybridization kinetics as quantified by surface plasmon resonance imaging (SPRI) system. Proc SPIE Int Soc Opt Eng 7192:71920C-71921-71920C-71929

Kane DE, Hellberg RS (2016) Identification of species in ground meat products sold on the U.S. commercial market using DNA-based methods. Food Control 59:158-163
Karabasanavar NS, Singh SP, Kumar D, Shebannavar SN (2014) Detection of pork adulteration by highly-specific PCR assay of mitochondrial D-loop. Food Chem 145:530-534

Kim M, Yoo I, Lee SY, Hong Y, Kim HY (2016) Quantitative detection of pork in commercial meat products by TaqMan real-time PCR assay targeting the mitochondrial D-loop region. Food Chem 210: 102-106

Kong C, Wang Y, Fodjo EK, Yang GX, Han F, Shen XS (2018) Loopmediated isothermal amplification for visual detection of Vibrio parahaemolyticus using gold nanoparticles. Microchim Acta 185:35

Köppel R, Ruf J, Rentsch J (2011) Multiplex real-time PCR for the detection and quantification of DNA from beef, pork, horse and sheep. Eur Food Res Technol 232:151-155

Kundapur RR, Nema V (2016) Loop-mediated isothermal amplification: beyond microbial identification. Cogent Biol 2:1137110

Lee SY, Kim MJ, Hong Y, Kim HY (2016) Development of a rapid onsite detection method for pork in processed meat products using real-time loop-mediated isothermal amplification. Food Control 66: $53-61$

Lou UK, Wong CH, Chen Y (2020) A simple and rapid colorimetric detection of serum lncRNA biomarkers for diagnosis of pancreatic cancer. RSC Adv 10:8087-8092

Mamikoglu B (2005) Beef, pork, and milk allergy (cross reactivity with each other and pet allergies). Otolaryngol Head Neck Surg 133:534 537

Man YBC, Mustafa S, Mokhtar NFK, Nordin R, Sazili AQ (2012) Porcine-specific polymerase chain reaction assay based on mitochondrial D-loop gene for identification of pork in raw meat. Int $\mathrm{J}$ Food Prop 15(1):134-144

Mane BG, Mendiratta SK, Tiwari AK (2013) Pork specific polymerase chain reaction assay for authentication of meat and meat products. $\mathrm{J}$ Meat Sci Technol 1(1):21-27

Martzy R, Kolm C, Krska R, Mach RL, Farnleitner AH, Reischer GH (2019) Challenges and perspectives in the application of isothermal DNA amplification methods for food and water analysis. Anal Bioanal Chem 411:1695-1702

Montiel-Sosa JF, Ruiz-Pesini E, Montoya J, Roncalés P, López-Pérez MJ, Pérez-Martos A (2000) Direct and highly species-specific detection of pork meat and fat in meat products by PCR amplification of mitochondrial DNA. J Agric Food Chem 48:2829-2832

Mori Y, Kanda H, Notomi T (2013) Loop-mediated isothermal amplification (LAMP): recent progress in research and development. J Infect Chemother 19:404-411

Murugaiah C, Noor ZM, Mastakim M, Bilung LM, Selamat J, Radu S (2009) Meat species identification and Halal authentication analysis using mitochondrial DNA. Meat Sci 83:57-61

Najian ABN, Syafirah EAREN, Ismail N, Mohamed M, Yean CY (2016) Development of multiplex loop mediated isothermal amplification (m-LAMP) label-based gold nanoparticles lateral flow dipstick biosensor for detection of pathogenic Leptospira. Anal Chim Acta 903: $142-148$

Napper DH (1984) Polymeric stabilization of colloidal dispersions. Academic Press, London

Nešić K, Stojanović D, Baltić MZ (2017) Authentication of meat and meat products vs. detection of animal species in feed - what is the difference? IOP Conf Ser Earth Environ Sci 85:012043

Notomi T, Okayama H, Masubuchi H, Yonekawa T, Watanabe K, Amino N, Hase T (2000) Loop-mediated isothermal amplification of DNA. Nucleic Acids Res 28(12):e63

Orbayinah S, Widada H, Hermawan A, Sudjadi S, Rohman A (2019) Application of real-time polymerase chain reaction using species specific primer targeting on mitochondrial cytochrome-b gene for analysis of pork in meatball products. J Adv Vet Anim Res 6(2): 260-265 
Pamies R, Cifre JGH, Espín VF, Collado-González M, Bañs FGD, de la Torre JG (2014) Aggregation behaviour of gold nanoparticles in saline aqueous media. J Nanopart Res 16:2376

Pinto AD et al (2015) Occurrence of mislabeling in meat products using DNA-based assay. J Food Sci Technol 52(4):2479-2484

Qiuhua C, Lu Y, Jun W, Yanlin C, Chaoyang D (2014) Colorimetric detection of hepatitis E virus based on reverse transcription loop mediated isothermal amplification (RT-LAMP) assay. J Virol Methods 197:29-33

Radwan SH, Azzazy HME (2009) Gold nanoparticles for molecular diagnostics. Expert Rev Mol Diagn 9(5):511-524

Rodríguez MA, García T, González I, Hernández PE, Martín R (2005) TaqMan real-time PCR for the detection and quantitation of pork in meat mixtures. Meat Sci 70:113-120

Seetang-Nun Y, Jaroenram W, Sriurairatana S, Suebsing R, Kiatpathomchai W (2013) Visual detection of white spot syndrome virus using DNA-functionalized gold nanoparticles as probes combined with loop-mediated isothermal amplification. Mol Cell Probes 27(2):71-79

Shehata HR, Li J, Chen S, Redda H, Cheng S, Tabujara N, Li H, Warriner K, Hanner R (2017) Droplet digital polymerase chain reaction (ddPCR) assays integrated with an internal control for quantification of bovine, porcine, chicken and turkey species in food and feed. PLoS One 12(8): e0182872

Sheikha AFE, Mokhtar NFK, Amie C, Lamasudin DU, Isa NM, Mustafa S (2017) Authentication technologies using DNA-based approaches for meats and halal meats determination. Food Biotechnol 31(4): 281-315

Suebsing R, Prombun P, Srisala J, Kiatpathomchai W (2013) Loopmediated isothermal amplification combined with colorimetric nanogold for detection of the microsporidian Enterocytozoon hepatopenaei in penaeid shrimp. J Appl Microbiol 114:1254-1263

Takano C, Seki M, Kim DW, Kilgore PE, Fuwa K, Takahashi K, Inazaki T, Hayakawa S (2017) Molecular serotype-specific identification of non-type b Haemophilus influenzae by loop-mediated isothermal amplification. Front Microbiol 8:1877

Tasrip NA et al (2019) Loop mediated isothermal amplification; a review on its application and strategy in animal species authentication of meat based food products. Int Food Res J 26(1):1-10

Temisak S et al (2020) Accurate determination of meat mass fractions using DNA measurements for quantifying meat adulteration. bioRxiv. https://doi.org/10.1101/2020.06.14.150375

Tomita N, Mori Y, Kanda H, Notomi T (2008) Loop-mediated isothermal amplification (LAMP) of gene sequences and simple visual detection of products. Nat Protoc 3(5):877-882
USDA (2018) Livestock and poultry: world markets and trade. United States Department of Agriculture, USA

Veigas B, Pedrosa P, Couto I, Viveiros M, Baptista PV (2013) Isothermal DNA amplification coupled to Aunanoprobes for detection of mutations associated to rifampicin resistance in Mycobacterium tuberculosis. J Nanobiotechnol 11:38

Wachiralurpan S, Sriyapai T, Areekit S, Sriyapai P, Augkarawaritsawong S, Santiwatanakul S, Chansiri K (2018) Rapid colorimetric assay for detection of Listeria monocytogenes in food samples using LAMP formation of DNA concatemers and gold nanoparticle-DNA probe complex. Front Chem 6:90

Walker HW, Grant SB (1996) Coagulation and stabilization of colloidal particles by adsorbed DNA block copolymers: the role of polymer conformation. Langmuir 12:3151-3156

Wang W, Wang X, Zhang Q, Liu Z, Zhou X, Liu B (2020) A multiplex PCR method for detection of five animal species in processed meat products using novel species-specific nuclear DNA sequences. Eur Food Res Technol 246:1351-1360

Watthanapanpituck K, Kiatpathomchai W, Chu E, Panvisavas N (2014) Identification of human DNA in forensic evidence by loop-mediated isothermal amplification combined with a colorimetric gold nanoparticle hybridization probe. Int J Legal Med 128:923-931

Weisbecker CS, Merritt MV, Whitesides GM (1996) Molecular selfassembly of aliphatic thiols on gold colloids. Langmuir 12:37633772

Wissiack R, Bdl C, Bordin G, Rodriguez AR (2003) Screening test to detect meat adulteration through the determination of hemoglobin by cation exchange chromatography with diode array detection. Meat Sci 64:427-432

Yang L, Fu S, Peng X, Li L, Song T, Li L (2014) Identification of pork in meat products using realtime loop-mediated isothermal amplification. Biotechnol Biotechnol Equip 28(5):882-888

Yusop MHM, Mustafa S, Che Man YB, Omar AR, Mokhtar NFK (2012) Detection of raw pork targeting porcine-specific mitochondrial cytochrome B gene by molecular beacon probe real-time polymerase chain reaction. Food Anal Methods 5:422-429

Zeng S, Yong KT, Roy I, Dinh XQ, Yu X, Luan F (2011) A review on functionalize gold nanoparticles for biosensing applications. Plasmonics 6:491-506

Zhao W, Brook MA, Li Y (2008) Design of gold nanoparticle-based colorimetric biosensing assays. ChemBioChem 9:2363-2371

Publisher's Note Springer Nature remains neutral with regard to jurisdictional claims in published maps and institutional affiliations. 